\title{
Model Pembelajaran Teknik Lompat Jangkit Dengan Metode Bermain di Sekolah Dasar
}

\author{
R. Sudarwo \& Yohanes \\ Fakultas Keguruan Ilmu Pendidikan Universitas Terbuka
}

\begin{abstract}
Abstrak: Penelitian ini bertujuan untuk memperoleh gambaran sejauhmana penerapan model pembelajaran teknik melompat jangkit dengan metode bermain dapat meningkatkan prestasi peserta didik di sekolah dasar. Hasil penelitian menunjukkan bahwa peserta didik lebih aktif terlibat dalam pembelajaran, mereka antusias melakukan lompat jangkit sambil bermain, sehingga dapat disimpulkan peserta didik merasa senang melakukan lompat jangkit dengan metode bermain, begitupun ketika peserta didik melakukan kesalahan dengan kesadaran dan tanggung jawab peserta didik melakukan push up dengan senang sebagai hukuman tanpa diminta oleh guru.
\end{abstract}

Kata kunci : teknik lompat jangkit, bermain, pendidikan jasmani, dan sekolah dasar

\begin{abstract}
This study aims to describe how far the application of learning models jump technique transmissible by playing methods to improve student achievement in elementary school. Results showed that students more actively involved in learning, they do jump transmissible enthusiastic while playing, so it can be concluded students feel happy to do the jump transmissible by playing methods, as well as students make the mistake of awareness and responsibility of learners doing push ups with pleasure as punishment without being asked by the teacher.
\end{abstract}

Key words: transmissible jump technique, playing, physical education, and elementary school

\section{Pendahuluan}

Pendidikan Jasmani sebagai bagian dari proses pendidikan secara keseluruhan, masih sering diartikan dan diinterprestasikan sebagai kegiatan pengajaran yang berupa aktifitas fisik dan demi fisik itu sendiri. Kerancuan dalam pemahaman pendidikan jasmani nampaknya masih banyak dan justru terdapat pada kalangan guru Pendidikan Jasmani itu sendiri. Masih banyak para guru pendidikan jasmani sendiri belum memahami sepenuhnya paradigma baru tentang Pendidikan Jasmani disekolah, umumnya mereka rata-rata masih menerapkan Pendidikan Olahraga yang selama ini dilaksanakan di sekolah. Padahal sangat berbeda sekali arti dan makna dari keduanya seperti yang terdapat pada Falsafah dan Pendidikan Jasmani.

Pendidikan jasmani dalam penyelenggaraan suatu program pendidikan ikut mendukung dan membantu tercapainya tujuan pendidikan anak didiknya. Untuk itu keberadaan Program Pendidikan Jasmani merupakan bagian penting dalam pendidikan di Sekolah, oleh karena itu Pendidikan Jasmani tidak boleh dianggap sebagai suatu yang bisa diabaikan atau sebagai pelengkap dalam penyelenggaran kurikulum sekolah. Menyikapi hal tersebut maka Pendidikan Jasmani di sekolah tidak bisa dianggap hanya sebagai pelajaran pelengkap saja, karena dengan pendidikan jasmani yang baik dan teratur bisa membantu perkembangan dan pertumbuhan anak, baik jasmani maupun rohaninya. Berdasarkan slogan "Mensana in corpore Sano" atau didalam tubuh yang sehat terdapat jiwa yang sehat, maka untuk mencapai tubuh sehat bagi peserta didik sekolah dasar (SD) dibutuhkan upaya guru untuk melakukan perubahan dalam pembelajarannya. Guru yang biasanya dalam pembelajaran Pendidikan Jasmani hanya meminta siswa melakukan senam massal saja. Sebagai pembaharuan guru harus mampu menerapkan model pembelajaran teknik melompat jangkit dengan metode bermain. Berdasarkan uraian tersebut permasalahan yang ingin dicari jawabnya yaitu sejauhmana penerapan model pembelajaran teknik melompat jangkit dengan metode bermain dapat meningkatkan prestasi peserta didik. Atas dasar permasalahan dimaskud maka tujuan penelitian ini yaitu untuk 
memperoleh gambaran sejauhmana pembelajaran teknik melompat jangkit dengan metode bermain dapat meningkatkan prestasi peserta didik di sekolah dasar.

\section{Kajian Literatur}

\section{Hakikat Pendidikan Jasmani.}

Pendidikan Jasmani adalah belajar keterampilan gerak, gerak manusia dimanipulasi dalam bentuk kegiatan fisik, seperti melalui permainan dan olahraga yang didalamnya terkandung nilai-nilai, sikap dan perilaku positif. Belajar keterampilan gerak dapat diartikan sebagai suatu rangkaian proses pembelajaran gerak yang dilakukan secara sistematis, terarah dan terencana. Secara spesifik hakekat Pendidikan Jasmani yaitu sebagai berikut: 1) Pemenuhan hasrat untuk bergerak; 2) Pengembangan Kesegaran Jasmani yang berkaitan dengan unsur keterampilan motorik dan kesehatan (komponen kebugaran Fisik); 3) Pengembangan Keterampilan; 4) Mentransformasikan nilai-nilai, atara lain appresiasi, percaya diri, harga diri, kooperatif, tanggung jawab, sportifitas, komperatif dan budaya hidup sehat; dan 5) Merangsang pertumbuhan dan perkembangan Jasmani juga Rohani secara menyeluruh yakni : kognitif, afektif dan psikomotor.

Dalam proses pembelajaran Pendidikan Jasmani, guru mengajarkan berbagai keterampilan gerak dasar, teknik dan strategi permainan olahraga internalisasi nilai-nilai (sportivitas, kejujuran, kerja sama, dan kebersamaan), dan pembiasaan-pembiasaan pola hidup sehat yang terus diamati dalam setiap pembelajarannya, bukan melalui pengajaran konvensional didalam kelas yang bersifat kajian teoritis. Aktivitasaktivitas yang diberikan dalam pengajaran Pendidikan Jasmani harus mendapat sentuhan didaktik metodik dari guru Pendidikan Jasmani, sehingga aktivitas yang dilakukan dapat mencapai tujuan pengajaran dengan baik.

\section{Definisi Pendidikan Jasmani.}

Pendidikan Jasmani adalah suatu proses yang dilakukan secara sadar dan sistimatik melalui kegiatan jasmani untuk memperoleh pertumbuhan jasmani, kesehatan dan kesegaran jasmani, keterampilan, kecerdasan dan perkembangan watak serta pribadi yang harmonis dalam rangka membentuk manusia Indonesia seutuhnya yang berkualitas berdasarkan Pancasila (Mutohir, 1996:4). Sementara itu, Bucher (1983) berpendapat bahwa Pendidikan Jasmani sebagai bagian integral dari proses pendidikan secara keseluruhan yang mempunyai tujuan dan sasaran untuk meningkatkan keterampilan manusia melalui media aktivitas jasmani yang telah diseleksi, dengan maksud mencapai tujuan. (Bucher, 1983:3). Sedangkan menurut kurikulum, Pendidikan Jasmani adalah proses pendidikan melalui penyediaan pengalaman belajar kepada peserta didik berupa aktivitas jasmani, bermain dan berolahraga yang direncanakan secara sistematis guna merangsang pertumbuhan dan perkembangan fisik, keterampilan motorik, keterampilan berfikir, emosional, sosial dan moral. Pembekalan pengalaman belajar itu diarahkan untuk membina, sekaligus membentuk gaya hidup sehat dan aktif sepanjang hayat. (Depdiknas, 2002: 1).

Walaupun definisi Pendidikan Jasmani berbeda-beda, tetapi mengandung persamaan dan dapat ditarik kesimpulan. Pendidikan melalui gerak jasmani, dan dapat dikatakan lebih lanjut bahwa Pendidikan Jasmani pada hakikatnya adalah proses pendidikan yang kegiatannya melibatkan interaksi antara peserta didik dengan lingkungan yang dikelola melalui aktivitas jasmani secara sistematis menuju pembentukan manusia seutuhnya. Aktivitas jasmani yang dimaksud adalah kegiatan untuk meningkatkan keterampilan motorik dan nilai-nilai fungsional yang mencakup kognitif, afektif dan sosial. Melalui Pendidikan Jasmani diharapkan seseorang dapat sehat, segar jasmaninya seiring dengan perkembangan keterampilan, pengembangan nilai sikap dan minat peserta didik. Aktivitas-aktivitas tersebut mencerminkan kesesuaian tujuan akhir, yaitu pendidikan secara utuh.

\section{Teori Belajar}

Belajar merupakan salah satu bentuk perilaku yang amat penting bagi kelangsungan hidup manusia. Belajar membantu manusia menyesuaikan diri (adaptasi) dengan lingkungannya. Dengan adanya proses belajar inilah manusia bertahan hidup (survived). Belajar secara sederhana dikatakan sebagai proses perubahan 
dari belum mampu menjadi sudah mampu, tejadi dalam jangka waktu waktu tertentu. Perubahan yang itu harus secara relative bersifat menetap (permanen) dan tidak hanya terjadi pada perilaku yang saat ini nampak (immediate behavior) tetapi juga pada perilaku yang mungkin terjadi di masa mendatang (potential behavior). Hal lain yang perlu diperhatikan ialah bahwa perubahan-perubahan tersebut terjadi karena pengalaman. Perubahan yang terjadi karena pengalaman ini membedakan dengan perubahan-perubahan lain yang disebabkan oleh kemasakan (kematangan).

Banyak ahli berpendapat bahwa belajar merupakan suatu proses yang asosiatif, yaitu asosiasi atau koneksi antara suatu rangsangan tertentu (stimulus) dengan reaksi tertentu (respons). Sementara itu ada yang menyatakan bahawa belajar secara sederhana memang dapat terjadi secara asosiatif, tetapi dalam proses belajar yang rumit, kompleks, persepsi serta pengertian akan situasi secara keseluruhan lebih memegang peranan. Selain itu belajar tidak semata-mata merupakan suatu akibat dari kondisi dalam lingkungan seperti pada model-model belajar klasikal dan instrumental conditioning, tetapi juga bisa terjadi karena mencontoh perilaku yang terjadi di sekitarnya.

Menurut pendekatan konstruktivisme, belajar adalah membangun dan memantapkan pengetahuan sebagai hasil transformasi pengalaman yang dilakukan melalui aneka ragam interaksi peserta didik dengan sumber. Dalam psikologi pendidikan prinsip yang paling penting menurut teori konstruktivis adalah guru tidak hanya sekedar memberi pengetahuan kepada peserta didik, peserta didik sendiri membangun pengetahuan di dalam pikirannya. Guru memberikan kemudahan dalam proses belajar dengan memberikan kesempatan kepada peserta didik menemukan sendiri dan mengajar peserta didik menjadi nalar dan secara sadar menggunakan strategi mereka sendiri untuk belajar. Hal tersebut diperjelas oleh Slavin (1994:225) bahwa "The teacher can give students ladder that lead to higher understandings, yet students themselves must clim these ladders". Hal tersebut mengisyaratkan bahwa guru dapat memberi jalan dan kesempatan kepada peserta didik yang dapat membantu mereka mencapai tingkat pemahaman yang lebih tinggi, namun harus diupayakan agar peserta didik sendiri yang melalui jalan tersebut (Slavin, 1994 :225).

\section{Hakikat Pembelajaran Pengertian Pembelajaran.}

Pembelajaran adalah operasionalisasi dari kurikulum, dalam hal ini adalah Garis-garis Besar Program Pengajaran. Pembelajaran di sekolah terjadi apabila terdapat interaksi guru dan peserta didik dengan lingkungan pembelajaran yang diarahkan untuk mencapai tujuan pembelajaran. Pembelajaran merupakan upaya membelajarkan peserta didik, yang secara implisit terlihat bahwa dalam pembelajaran ada kegiatan memilih, menetapkan dan mengembangkan metode untuk mencapai untuk mencapai hasil yang diinginkan. Dari definisi ini dapat dikatakan bahwa pembelajaran adalah upaya guru yang bertujuan dalam artian bahwa tujuan tersebut adalah guru membelajarkan peserta didik untuk mencapai tujuan belajar.

Pembelajaran dapat diartikan sebagai upaya menciptakan kondisi yang memungkinkan peserta didik dapat belajar. Pembelajaran merupakan upaya untuk membelajarkan peserta didik, pembelajaran lebih mengutamakan pada bagaimana upaya guru mendorong atau memfasilitasi peserta didik belajar, bukan pada apa yang dipelajari peserta didik. Istilah pembelajaran adalah menggambarkan bahwa peserta didik lebih banyak berperan dalam mengkontruksikan pengetahuan bagi dirinya dan bahkan pengetahuan itu bukan hasil transformasi dari guru.

Bucher. C.A., (1983) mengemukakan bahwa pembelajaran Pendidikan Jasmani dapat disebut ilmu apabila memenuhi karateristik sebagai berikut: a) memiliki daya ramal dan kontrol terhadap hasil belajar; b) dapat dievaluasi secara sistematik dan dapat dipecah menjadi rangkaian kegiatan yang dapat dikuasai; c) mengandung pemahaman tentang tingkah laku, desain instruksional, penyampaian dan manajemen; d) berkaitan erat dengan prinsip belajar seperti kesiapan, motivasi, pelatihan, umpan balik dan kemajuan secara urutan; dan e) di mungkinkan unuk mengkaji pengajaran "Teoritical Scientific Perspektif"

Berdasarkan karakteristik pembelajaran tersebut di atas dapat disimpulkan bahwa pendidikan jasmani sebagai salah satu komponen 
pembelajaran tidak akan berarti, apabila guru mengalami kesulitan dalam memahami dan melaksanakan pembelajaran. Jika implementasinya dapat dicapai melalui pembelajaran pendidikan jasmani, maka guru diharapkan dapat meningkatkan kemampuannya dalam melaksanakan proses pembelajaran sesuai dengan tuntutan kurikulum yang berlaku. Berdasarkan hal tersebut menunjukkan, bahwa melalui pembelajaran Pendidikan Jasmani peserta didik diharapkan memiliki pengembangan keterampilan gerak, pemahaman kognitif, dan sikap positif terhadap aktivitas jasmani, agar kelak menjadi manusia dewasa yang sehat, segar jasmani dan rohani serta memiliki kepribadian yang mantap. Apabila kita kaji lebih jauh lagi tentang konsep pengajaran, maka konsep pengajaran mengandung konotasi guru, sedangkan konsep peserta didik adalah yang aktif belajar. Konsep pengajaran dan konsep pembelajaran dapat disimpulkan tidak mengandung makna yang berbeda dan sering digunakan secara bergantian. Pengajaran lebih menekankan upaya guru dalam membelajarkan peserta didik mencapai tujuan kurikulum. Adapun Pembelajaran menekankan pada proses yang menggambarkan peserta didik lebih banyak berperan dalam mengkonstruksi pengetahuan bagi dirinya dan pengetahuan itu adalah bukan hasil transformasi dari guru. Jadi pembelajaran adalah upaya untuk membelajarkan peserta didik melalui kegiatan proses belajar mengajar antara guru dengan peserta didik dalam mengembangkan metode untuk hasil yang diinginkan.

\section{Tujuan Pembelajaran.}

Tujuan utama pendidikan jasmani yaitu membantu peserta didik agar dapat meningkatkan keterampilan gerak mereka. Di samping itu, agar peserta didik merasa senang dan mau berpartisipasi dalam berbagai aktivitas. Tujuan ini mengisyaratkan, apabila peserta didik telah memiliki fundasi keterampilan gerak, dan sikap yang positif terhadap aktivitas jasmani, maka kelak akan menjadi manusia dewasa yang sehat dan segar jasmani dan rohani serta memiliki kepribadian yang mantap. Untuk mencapai tujuan ini diharapkan guru tidak berperan sebagai pemberi pengetahuan tetapi lebih berperan sebagai fasilitator yang memungkinkan peserta didik dapat mengaktifkan seluruh unsur dinamis dalam proses belajar, yang dapat mengarahkan peserta didik pada kegiatan kontruksi ilmu pengetahuannya. Tujuan yang dimaksud adalah hasil belajar. Di samping pendapat lainnya yang dikemukakan, proses belajar pada individu-individu di sekolah merupakan faktor penentu keberhasilan belajar, oleh sebab itu maka terlebih dahulu diperlukan suatu rancangan pembelajaran yang formal dan sistematis. Hal tersebut mengindikasikan bahwa pengetahuan atau keterampilan yang dicapai peserta didik adalah sebagai hasil belajar dan pembelajaran yang diterimanya di sekolah. Pendapat lain yang berkaitan dengan belajar pendidikan jasmani mengemukakan pendapatnya bahwa kesiapan fisik dan mental untuk belajar apa saja merupakan komponen dalam belajar keterampilan/skill adalah kesiapan. Kesiapan belajar mengarah pada kesadaran menerima instruksi dan pencapaian tujuan, karena setelah belajar diharapkan terjadi perubahan dalam diri peserta didik/peserta didik yang belajar. Misalnya dari tidak tahu menjadi tahu, dari tidak tidak bisa melakukan menjadi bisa melakukan, dari tidak terampil menjadi terampil. Jadi tujuan ini secara eksplisit diupayakan melalui kegiatan pembelajaran. Tujuan suatu pembelajaran akan tercapai apabila peserta didik telah siap untuk belajar. Kesiapan yang dimaksudkan agar terjadi perubahan tingkah laku, bukan pada aspek kognitif saja, tetapi juga pada aspek lainnya seperti afektif dan psikomotor.

\section{Kreativitas}

Dewasa ini istilah kreativitas atau daya cipta sering digunakan dalam kegiatan manusia sehari-hari, sering pula ditekankan pentingnya pengembangan kreativitas baik pada anak didik, pegawai negeri maupun pada mereka yang berwiraswasta. Kreativitas biasanya diartikan sebagai kemampuan untuk menciptakan suatu produk baru. Ciptaan itu tidak perlu seluruh produknya harus baru, mungkin saja gabungannya, kombinasinya, sedangkan unsur-unsurnya sudah ada sebelumnya, kombinasi baru, atau melihat hubunganhubungan baru antara unsur, data, atau hal-hal yang sudah ada sebelumnya.

Kreativitas terletak pada kemampuan untuk melihat asosiasi antara hal-hal atau obyek-obyek 
yang sebelumnya tidak ada atau tidak tampak hubungannya. Seorang anak kecil asyik bermain dengan balok-balok yang mempunyai bentuk dan warna yang bermacam-macam, setiap kali dapat menyusun sesuatu yang baru, artinya baru bagi dirinya karena sebelumnya ia belum pernah membuat hal yang semacam itu. Anak ini adalah anak yang kreatif, berbeda dengan anak lain yang hanya membangun sesuatu jika ada contohnya.

Terdapat empat prinsip dasar sinektik tentang kraetivitas. Pertama, kreativitas merupakan sesuatu yang penting dalam kegiatan sehari-hari. Hampir semua manusia berhubungan dengan proses kreativitas, yang dikembangkan melalui seni atau penemuan-penemuan baru. Lebih jauh Gordon menekankan bahwa kreativitas merupakan bagian dari kehidupan kita sehari-hari dan berlangsung sepanjang hayat. Kedua, proses kreatif bukanlah sesuatu yang misterius. Hal tersebut dapat diekspresikan dalam gerakan dalam lompat jangkit atau mungkin membantu orang secara langsung untuk meningkatkan kreativitasnya. Secara tradisional, kreativitas didorong oleh kesadaran yang memberi petunjuk untuk mendeskripsikan dan menciptakan prosedur latihan lompat jangkit yang dapat diterapkan dalam pembelajaran Pendidikan Jasmani di sekolah atau lingkungan lain. Ketiga, penemuan kreatif sama dalam semua bidang, baik dalam bidang seni, ilmu, maupun dalam rekayasa. Selain itu, penemuan kreatif ditandai oleh beberapa proses intelektual. Keempat, berpikir kraetif baik secara individu maupun kelompok adalah sama. Individu dan kelompok menurunkan ide-ide dan produk dalam berbagai hal.

Proses pembelajaran pada hakekatnya untuk mengembangkan aktivitas dan kreativitas peserta didik, melalui berbagai interaksi dan pengalaman belajar. Namun, dalam pelaksanaannya seringkali tidak disadari guru, bahwa masih banyak kegiatan pembelajaran yang dilaksanakan justru menghambat aktivitas dan kreativitas peserta didik.

\section{Fungsi Bermain dalam Pendidikan Jasmani. Teknik Dasar lompat Jangkit.}

Lompat jangkit sering juga disebut dengan lompat jingkat atau lompat tiga (triple jump). Namun istilah atau nama yang resmi digunakan di Indonesia, yaitu yang tercantum di dalam buku peraturan perlombaan yang dikeluarkan oleh Persatuan Atletik Seluruh Indonesia (PASI) adalah Lompat Jangkit (HOP - STEP JUMP). Berdasarkan teori pada buku peraturan perlombaan dan $A D /$ ART PASI 1990-1991 pasal 174 ayat 1 dan 2 yang menyebutkan: 1) Lompat jangkit adalah suatu lompat yang terdiri dari jingkat (HOP), sebuah langkah (STEP) dan sebuah lompatan (JUMP) terjadi urut seperti ini, 2) Jangkit dilakukan dengan si pelompat mendarat dengan kaki yang sama sesudah bertolak atau kaki tolak (kaki tumpu dipakai mendarat disusul dengan satu langkah penuh yang mendarat menggunakan kaki yang lain dan diakhiri dengan gerakan lompat) (PASI, 1991: 151).

\section{Model pembelajaran lompat jangkit dengan metode bermain}

Bermain dan permainan merupakan bagian hidup dan kehidupan manusia, khususnya bagi anakanak, bermain tidak bisa dipisahkan dari mereka. Matakupan berpendapat; bahwa bermain adalah pekerjaan yang dilakukan dengan senang hati, akan tepat sekali bila bermain dan permainan dijadikan modal utama dalam menciptakan situasi belajar (Matakupan, 1993: 5).

Lompat jangkit merupakan salah satu nomor atletik yang tercantum dalam GBPP, dan merupakan mata pelajaran inti yang wajib diikuti oleh semua peserta didik. Agar pembelajaran atletik menyenangkan, maka pembelajaran perlu dimodifikasi dan disesuaikan dengan tingkat pertumbuhan dan perkembangan anak.

Menurut ahli atletik Lange Gunter berpendapat bahwa: Atletik dapat dilakukan secara bermain ditujukan pada aspek aktivitas bermain dalam atletik. Fokusnya pada saran-saran dan kemungkinan-kemungkinan pendidikan atletik yang dapat dipandang dari berbagai segi, menarik dan penuh event (Lange Gunter, 1995: 1)

Untuk itu, permainan Atletik yang digunakan dalam proses pembelajaran keterampilan dasar lompat jangkit perlu mengutamakan unsur kegembiraan dan kesenangan. Permaianan Atletik merupakan modifikasi mater pembelajaran keterampilan dasar lompat jangkit sebagai pelatihan awal/pendahuluan untuk memudahkan peserta didik melakukan teknik dasar sebelum teknik dasar yang sebenarnya. Modifikasi merupa- 
kan merupakan penyederhanaan dari peraturan sarana dan prasarana telah diubah dan disesuaikan dengan kebutuhan dan kemampuan peserta didik. Ini berarti dengan modifikasi diharapkan suasana pembelajaran keterampilan dasar lompat jangkit lebih menarik dapat dilakukan dan diikuti peserta didik tanpamerasa takut dan gagal dalam tugas gerak.

Implementasi Pendekatan pola gerak dominan dalam pembelajaran Atletik di Sekolah Dasar meliputi: 1) Proses Pembelajaran yang hanya berorientasi kepada hasil tanpa memperhatikan variasi dan proses pengembangannya sering menjebak peserta didik dalam kebosanan; 2) Pendekatan yang dapat membantu menyegarkan kembali nuansa Atletik yang sementara ini dianggap sebagai pembelajaran yang monoton, membosankan dan tanpa variasi adalah melalui dimensi ritmik dan permainan; dan 3) Ritmik dan permainan adalah suatu daya kehidupan yang vital dan dapat menimbulkan kegembiraan, kegairahan, kelincahan, relaksasi, yang bermanfaat untuk memudahkan timbulnya inspirasi.

Manfaat permainan dalam pembelajaran Atletik, meliputi: 1) Mengembangkan gerak berirama; 2) Memberikan nuansa kompetisi/ perlombaan dalam persaingan diantara peserta didik; 3) Penggunaan alat bantu yang variatif dapat digunakan dalam permainan dapat memberikan kegembiraan dan kepuasan kepada peserta didik; 4) Penggunaan alat bantu yang menarik dan mudah, menempatkan peserta didik pada penguasaan yang penuh, sehingga mereka tidak segan-segan mengambil resiko untuk memperoleh kemenangan; dan 5) Menguji ketangkasan yang tersembunyi (menggali kompetensi peserta didik).

\section{Pelaksanaan pembelajaran teknik lompat jangkit dengan metode bermain}

Hasil belajar, menyeleksi dan menkombinasikan keterampilan-keterampilan teknik-teknik dan ideide yang sesuai dengan olahraga perorangan (Atletik). Beberapa indikator: 1) Mendemontrasikan teknik yang baik dalam semua tahap lari atau nomor-nomor lari; 2) Mengaplikasikan berbagai teknik lompat jauh, lompat jangkit dan lompat tinggi; 3) Memilih pendekatan dengan event yang dihadapi; 4) Melakukan berbagai usaha dalam kompetisi; dan 5) Menekankan kapan menggunakan power dan kapan menggunakan kontrol yang baik.

\section{Metodologi}

Sampel dalam penelitian ini yaitu peserta didik kelas lima sekolah dasar yang memperoleh mata pelajaran pendidikan jasmani. Waktu yang digunakan dalam pengambilan data adalah tiga jam pelajaran, dengan rincian dua jam untuk pelaksanaan pembelajaran dan satu jam untuk evaluasi (tes). Dalam melaksanakan pembelajaran guru menggunakan alat peraga lompat jangkit yaitu kertas warna merah berbentuk persegi panjang dan kertas warna biru berbentuk lingkaran. Kertas warna merah harus diinjak oleh kaki kanan dan kertas warna biru berbentuk lingkaran diinjak oleh kaki kiri dengan metode bermain. Kemudian kertas-kertas warana tersebut diatur sesuai kebutuhan. Pada awalnya kertas warna warni disusun dengan berurutan sehingga peserta didik mudah melakukannya kemudian, kemudian susunan kertas diatur secara tidak berurutan sehingga peserta didik memerlukan pemikiran dan pemahaman untuk melakukan injakan kaki pada kertas-kertas tersebut dan agar tidak salah.

Untuk melakukan pengamatan pembelajaran digunakan pedoman observasi dan untuk meminta pendapat peserta didik tentang rasa senang dan rasa puas pada model pembelajaran teknik lompat jangkit dengan metode bermain digunakan kuesioner.

Hasil pengamatan langsung dan kuesioner dilakukan analisis untuk melihat hubungan antara pengamatan langsung dengan hasil kuesioner. Di samping itu, dilakukan studi dokumentasi dengan membandingkan antara prestasi peserta didik sebelum penerapan model pembelajaran teknik lompat jangkit dengan metode bermain dan setelah penerapan model pembelajaran tersebut, apakah ada peningkatan prestasi peserta didik?

\section{Hasil Penelitian dan Pembahasan}

Pada awal pembelajaran guru meminta peserta didik melalukan pemanasan di lapangan dengan berlari-lari kecil berkeliling lapangan sebanyak tiga kali. Semua mata peserta didik tertuju pada kertas berwarna-warni dengan bentuk yang berbeda. 
Kertas warna tersebut dibentuk lingkaran, persegi panjang di tengah lapangan. Guru mulai melakukan pembelajarannya. Dengan meminta peserta didik menginjak kertas-kertas berwarna tadi dengan menjelaskan kertas-kertas tadi sebagai alat Bantu lompat jangkit.

Untuk kertas warna merah berbentuk persegi panjang sebagai tanda dan boleh diinjak dengan kaki kanan, sedangkan kertas warna biru berbentuk lingkaran sebagai tanda dan diinjak dengan kaki kiri. Guru menyusun kertas warnawarni tadi dengan urutan yang tidak sama yaitu merah-biru-merah-biru sebanyak enam merah dan enam biru. Guru meminta peserta didik melakukan jalan diatas kertas warna merah dan biru dengan kaki kanan harus menginjak kertas warna merah dan kaki kiri menginjak warna biru. Semua peserta didik melakukannya sebanyak tiga kali, sebagai pemanasan dan menghafal kaki mana yang digunakan untuk menginjak kertas warna-warni. Bagi peserta didik yang melakukan kesalahan diberi hukuman dengan push up sebanyak tiga kali. Selanjutnya, peserta didik diminta lari-lari kecil di atas kertas warna-warni tadi, sesuai kesepakatan jika peserta didik melakukan kesalahan menginjak kertas warna akan mendapat hukuman. Kemudian kertas warna-warni diatur dengan jaraknya satu dengan yang lainnya agak brejauahan, dan peserta didik melakukan lari yang agak lebih cepat dari yang terdahulu. Sambil memberi istirahat dan peserta didik berpikir, guru mengatur karpet lebih agak sulit dengan cara tidak beraturan. Kemudian, peserta didik diminta melakukan lari kecil atau melangkah cepat di atas kertas warna-warni tadi. Sesuai dengan kesepakatan bersama peserta didik yang melakukan kesalahan menginjak kertas warna-warni tadi tetap diberi hukuman untuk memotivasi peserta didik agar tidak melakukan kesalahan.

Permainan dilakukan dua atau tiga kali sampai peserta didik tidak melakukan kesalahan lagi. Setelah itu peserta didik diminta beristirahat sejenak dan guru mengatur kembali susunan kertas warna-warni secara tidak teratur dan cukup sulit dan dengan jarak antara kertas warna merah dan warna biru tertentu dengan tujuan adanya keseimbangan. Setelah istirahat guru meminta peserta didik berlari satu persatu sesuai absensi untuk dinilai. Dalam melakukan penilaian guru bersikap luwes dan fleksibel dan tidak kaku, sehingga peserta didik tidak merasa sedang dinilai oleh guru karena situasi peserta didik dalam kondisi bermain sehingga tidak ada perasaan takut atau cemas akan melakukan kesalahan dalam lompat jangkit. Peserta didik merasa senang melakukan permainana tersebut meskipun dinilai oleh guru, peserta didik tetap bergembira dan bersenda gurau dengan temantemannya. Gurupun tidak mengalami kesulitan dalam melakukan penilaian karena semuanya berjalan dengan wajar dan dalam situasi bermain.

Meskipun peserta didik dihadapkan pada permainan yang agak menantang lagi karena harus melakukan gerak kaki dan berpikir untuk tidak melakukan kesalahan. Namun semua itu dilakukan dengan hati gembira dan dalam situasi bermain sehingga semuanya berjalan lancer. Setelah semua peserta didik melakukan tugasnya dan dinilai, guru meminta peserta didik istirahat dan berganti pakaian untuk mengikuti pelajaran selanjutnya. Sambil beristirahat telihat jelas wajah peserta didik tampak senang dan gembira meskipun badan letih.

Kreativitas guru menciptakan media pembelajaran berupa kertas warna yang dibentuk persegi panjang maupun lingkaran yang digunakan untuk permainan dalam lompat jangkit sangat baik sekali dan membuahkan hasil yang positif. Prestasi belajar peserta meningkat. Sebelumnya pada pembelajaran yang dilakukan guru nilai ratarata siswa 6,38 namun setelah guru menerapkan model pembelajaran teknik lompat jangkit dengan metode bermain nilai rata siswa menjadi 7,28. Hal tersebut menunjukkan bahwa kreativitas yang dilakukan guru tidak sia-sia. Tampaknya memang sederhana, hanya berupa kertas yang dibentuk bangun datar, namun bagi peserta didik sangat memotivasi untuk melakukan suatu hal yang terbaiknya. Baik dalam melakukan lompatan maupun saat menjalani hukuman apabila peserta didik melakukan kesalahan dalam menginjak kertas warna warni sesuai dengan kesepakatan. Dalam diri peserta didik telah tertanam rasa tanggung jawab sportivitas yang tinggi. Selain itu, telah dapat memotivasi peserta didik untuk berbuat jujur.

Apabila peserta didik melakukan kesalahan, dengan menginjak kertas warna dengan kaki yang 
salah maka dengan suka rela peserta didik akan menjalani hukuman tanpa diminta oleh guru atau teman-temanya. Dengan penuh kesadaran dan rasa tanggung jawab yang tinggi peserta didik akan menjalani hukuman dengan melakukan push up sebanyak tiga kali. Apabila kebiasaan berbuat jujur terus dikembangkan dan dipelaihara, maka pada akhirnya tercipta manusia-manusia unggulan sebagai sumber daya yang berkualitas, jujur sehingga mampu bersaing di era global.

Dalam melaksanakan pembelajaran, guru telah dapat membuat peserta didik merasa senang dan tidak tertekan ataupun takut. Apabila peserta didik selalu merasa senang pada setiap mengikuti pembelajaran, maka peserta didik juga akan menyenangi materi yang diajarkan guru maupun mata pelajaran tersebut secara utuh. Apabila dalam setiap pembelajaran guru selalu merujuk pada prinsip pembelajaran adalah pembelajaran yang melibatkan peserta didik secara aktif, membuat peserta didik kreatif dan pembelajaran tersebut berlangsung secara efektif dan juga menyenangkan peserta didik (PAKEM). Peserta didik merasa senang dalam melakukan proses belajar, semua yang diberikan guru dapat dipahami dengan baik dan diterapkan dengan baik pula. Jika setiap pembelajaran yang dilaksanakan guru menampilkan kreativitas-kreativitasnya yang menyenangkan. Dengan demikian, peserta didik juga terpacu untuk melakukan kreativitas. Peserta didik dapat media pembelajaran sesuai materi yang diajarkan dan dicontohkan guru maupun alat-alat atau media lainya yang baru sebagai hasil kreativitasnya. Pada akhirnya akan tercipta manusia-manusia yang kreatif yang dapat menciptakan ide atau sesuatu yang baru berdasarkan contoh yang telah ada, atau sesuatu yang baru sama sekali.

\section{Simpulan dan Saran Simpulan}

Pada awalnya susunan kertas diatur untuk memudahkan peserta didik melakukan injakan. Apabila peserta didik melakukan kesalahan lompatan atau menginjak kertas dengan kaki yang salah maka diberi hukuman. Hukumannya, melakukan push up sebanyak tiga kali. Karena lompatan dilakukan sambil bermain maka peserta didik tidak merasa takut mendapat hukuman apabila melakukan kesalahan. Kertas disusun kembali dengan susunan agak sulit dengan maksud agar peserta didik berpikir terlebih dahulu sebelum melakukan lompatan. Tanpa disadari peserta didik telah dapat menghadapi tantangan yang cukup sulit yang diberikan guru dan peserta didik melakukan lompat jangkit dengan baik tanpa kesalahan. Terjadi peningkatan prestasi, sebelumnya nilai rata-rata siswa 6,38 dan setelah penerapan model pembelajaran menjadi 7,28.

Peserta didik merasa senang melakukan lompat jangkit dengan metode bermain, setiap melakukan lompat jangkit dilakukannya dengan senang dan gembira begitupun ketika peserta didik melakukan kesalahan maka kesadaran dan tanggung jawab peserta didik melakukan push up dengan senang sebagai hukuman tanpa diminta oleh guru. Saat guru melakukan penilaian terhadap gerakan lompat jangkit tidak ada satupun peserta didik yang melakukan kesalahan, semua peserta didik berhasil melakukan lompat jangkit dengan sempurna. Ketika peserta didik selesai melakukan lompat jangkit dengan penuh canda peserta didik beristirahat berganti pakaian olah raga dengan seragam sekolah putih-merah kembali untuk mengikuti pelajaran selanjutnya.

\section{Saran}

Guru agar selalu berusaha membuat persiapan pembelajaran dengan sebaik-baiknya, mengacu pada pembelajaran yang berpusat pada peserta didik. Peserta didik menjadi tolok ukur pembelajaran yang dilaksanakan guru sehingga guru akan selalu berusaha membuat peserta didik merasa senang dalam setiap pembelajaran.

Guru Pendidikan Jasmani sebaiknya terlibat langsung dalam seluruh kegiatan pembelajaran dan memperhatikan peserta didik dengan seksama jangan membiarkan peserta didik melakukan gerakan atau permainan sesuai kemauan peserta didik dan guru hanya duduk-duduk saja di pinggir lapangan sementara peserta didik berada di tengah lapangan. Apabila setiap pembelajaran yang dilaksanakan guru dapat melibatkan peserta didik secara aktif dan kreatif, dan peserta didik merasa senang maka sangat dimungkinkan akan tercipta manusia-manusia unggul sebagai sumber daya yang berkualitas yang mempu bersaing di era global sekarang ini. 


\section{Pustaka Acuan}

Bucher, C.A. 1983. Foundation of Physical Education and Sport, St. House CV. Mosby.

Departemen Pendidikan Nasional, 2002, Kurikulum Berbasis Kompetensi. Jakarta.

Lange Gunter. 1995. Manual Aktual Knowladge for Indonesia Level I Coacher, Jakarta.

Matakupan. 1993. Materi Pokok Teori Bermain, Jakarta.

Mutohir. 1996. Pengembangan Model Pembelajaran Pendidikan Jasmani di Sekolah Dasar, Lembaga Penelitian IKIP Surabaya.

Persatuan Atlet Seluruh Indonesia. 1991. Anggaran Dasar dan Rumah Tangga, PASI 1990-1991 Jakarta.

Slavin, R.E. 1994. Educational Psychology: Theory Research and Practice. Second Edition. Boston: Allyn and Bacon. 